\title{
Employees as Individually and Collectively Acting Subjects-Key Contributions from Nordic Working Life Research
}

\section{Peter Hasle}

Professor, Department of Business and Management, Aalborg University ${ }^{1}$

\section{Ole Henning Sørensen}

Associate Professor, Department of Business and Management, Aalborg University

\begin{abstract}
The Nordic countries - Denmark, Finland, Iceland, Norway, and Sweden - are societies that share many features among themselves that also distinguish them from other industrialized countries. The paper poses the question whether the distinct character of the Nordic societies has generated working life research that is clearly distinguishable from similar research in other countries in terms of distinctness in topics, methods, empirical findings, or theoretical concepts. The aim of this paper is to answer this question by identifying, analyzing, and discussing selected key contributions from Nordic working life research to understand how they research and construe the conditions of humans at work with a special focus on the psychosocial well-being of industrial workers. The paper concludes that the key contributions to Nordic working life research have a distinctive emphasis on collective employee voice and autonomy and an extensive use of empirical and actionoriented research methods. Employees are construed not only as workers resisting exploitations from management or as workers pursuing individual careers, but also as members of collectives who share ideas and aspirations and who legitimately influence the management (and research) using cooperation and pressure.
\end{abstract}

\section{KEY WORDS}

Workers' collective / control / socio-technique / collective bargaining / collaboration / employee influence

\section{Introduction}

he Nordic countries-Denmark, Finland, Iceland, Norway, and Sweden-are societies that share many features among themselves that also distinguish them from other industrialized countries. Important features are related to the welfare society (Esping-Andersen, 1990), welfare research, income distribution and gender equality (Erikson et al., 1987), social policy (Kangas \& Palme, 2009), and to the labor market (Gallie, 2003; Kettunen, 2012; Schiller et al., 1993). The communality among these societies is often termed the Nordic model and although the similarities in the content and demarcation of this model are debated, for example, discussions about the Danish

\footnotetext{
${ }^{1}$ E-mail: hasle@business.aau.dk
} 
flexicurity model (Madsen, 2004), it is generally recognized that specific similarities observed among the Nordic countries do warrant the usage of the term "Nordic model" (Gallie, 2009; Gustavsen, 2011). The two most frequently mentioned features of the Nordic model, particularly in Scandinavia-Denmark, Norway, and Sweden-are these features: the system of collective bargaining in the labor market and the solidarity-based welfare system with relatively high social security (Kasvio et al., 2012).

One question that arises in this context is whether the distinct character of the Nordic societies has generated working life research that is clearly distinguishable from similar research in other countries in terms of distinctness in topics, methods, empirical findings, or theoretical concepts. This paper argues that Nordic working life research has generated contributions that can be differentiated from working life research in other countries. This does not mean that Nordic research has lived in a closed system without any contact with international research. On the contrary, Nordic research has in many respects received important inspirations from international research. An important example of this phenomenon is the initial work by Trist and Bamforth (1951) on socio-technical systems which gave inspiration for the Norwegian projects in the 1960s (Emery \& Thorsrud, 1969; Thorsrud \& Emery, 1964).

The aim of this paper is to identify, analyze, and discuss selected key contributions from Nordic working life research to understand how they research and construe the conditions of humans at work with a special focus on the psychosocial well-being of industrial workers. The distinctive character of this research has been made possible in the context of the Nordic countries where it has been carried out, and this context is therefore the point of departure for this paper. We follow up by explaining how we selected the particular working life research to include in the analysis in the paper. Priority has been given to classic research such as the workers' collective (Lysgaard, 1961), the socio-technical systems (Thorsrud \& Emery, 1970), and the work on workplace democracy and employee control in Sweden (Gardell \& Svensson, 1981; Karasek \& Theorell, 1990; Karasek et al., 1987). The results from these classic works of research are presented and analyzed in order to identify particular Nordic contributions. Subsequently, we use this analysis to compare Nordic research with other major working life research contributions such as labor process, occupational medicine, and human resource management. The paper concludes with an outlook on future research perspectives.

The main contribution of this paper is to stress the point that Nordic working life research has a distinctive emphasis on the voice of employees-who are not only seen as workers resisting exploitations from management or as workers pursuing individual careers, but also as members of collectives who share ideas and aspirations while influencing the management using cooperation and pressure.

\section{The Nordic context}

Historians discussing the origins of the Nordic research model have pointed out some of its important elements. These elements include the influence that certain common historical events have had in the Nordic context. Some such events were egalitarian peasants who allied with the kings in opposition to the nobles (Gudmundsson, 1993), integration of the protestant church in the state (Trägårdh \& Linberg, 2004), and the development of high social capital over several centuries through compromises and agreements such 
as the Kalmar Union (Bjørnskov et al., 2011). Such common historical events were perhaps a reason for the parallel developments that took place from the late 19th century in Denmark, Sweden, and Norway, while Finland, probably because of its special relations with Russia and Iceland and because of its geographical isolation, has to some extent deviated from similar developments in the Scandinavian countries.

The advent of industrialization in Scandinavian countries happened later than in the countries of central Europe; it was followed by the rise of social democracy at the political level, leading to the development of a solidarist social welfare system in all of these countries. In the labor market, both employers' and employees' organizations achieved high membership rates and thereby high density. All countries developed systems for centralized collective bargaining with relatively low state interference (Due \& Madsen, 2008; Gallie, 2009; Philips \& Eamets, 2007). One important feature of this scenario was the development of mutual recognition of the legitimacy of the other party. In Denmark, the point of departure for the mutual recognition was included in the September settlement which was concluded after a month-long general strike and lockout in 1899 . Similar agreements were concluded in Norway 1935 and Sweden 1938 (Fahlbeck \& Mulder, 2009; Johansson, 1998). This mutual recognition is a very distinctive characteristic of the Nordic labor market, whereas most of the other industrialized countries up to our time have been marked by continuous conflict regarding the recognition of unions and the legitimacy of capitalist ownership. These early agreements were followed up by collective bargaining agreements that settled wages and working times and subsequently developed systems for local representation with shop stewards and collaboration committees (joint works councils) (Due et al., 1994; Falkum et al., 2009).

While the industrial relations system was initiated by the concerned parties themselves, it was subsequently institutionalized by the state through legislation by establishing labor courts for arbitrating conflicts to ensure peaceful relations in the labor market. An important point of note is that these labor courts are controlled to a large extent by the parties themselves. The legitimacy of the two parties was further institutionalized by their integration in a number of official committees and boards regarding for instance the working environment and the vocational education. Norway, in 1885, had established a worker commission with participation from workers, employers, and the government. It was the commission that suggested Norwegian legislation on factory inspection (Falkum et al., 2009). In Denmark, a tripartite national council was established in 1901 which advised the Danish Government on working environment legislation, and it still exists—now named the Working Environment Council. The state copied the local representative system in the working environment acts, establishing elected working environment representatives, joint working environment committees, and working environment activities which are to be carried out in collaboration between management and employees (Frick et al., 2004; Jacobsen, 2011).

One important consequence of the widespread self-regulating collective bargaining system is that worker rights' legislation on issues such as minimum salary and working hours has been very limited, when viewed in contrast with the Continental welfare systems that have been built upon an extensive set of legislated worker rights. Kettunen (2012) suggests that a particular form of social citizenship has evolved in the Nordic countries where interests rather than rights have been central. It can be deduced that the legitimate and egalitarian interests of stakeholders form the bases for compromises among these interests. It is furthermore the experience of stakeholders that they 
can safeguard their own interests through these compromises. One such example is the introduction of Tayloristic organizational principles in the Nordic countries in the 1950s (Gustavsen, 2011; Hasle \& Møller, 2007). The introduction of Taylorism led to negotiated agreements between employers and unions which, on the one hand, secured the productivity increase pursued by employers and, on the other hand, secured more influence for unions that resulted in salary increases and joint union-employer time and motion studies. Although the deployment of Tayloristic principles seems to imply the existence of a problematic working environment, it was actually the case that the unions had strong influence on the speed and level of the implementation of these negotiated agreements.

Several societal developments that took place during the last decade, for example, a decline in union density, an increase in global competition, and the emergence of certain political reservations against the benefits of the labor market systems, seem to have challenged the Nordic collaborative model-thus weakening its foundations. The progress of collaboration has therefore stalled in some labor market areas. The financial crisis has reinforced these tendencies due to the high unemployment rate and strong state intervention. The question as to how the model will develop in the future is therefore now open (Due \& Madsen, 2008).

Even though these developments of the last decade are highly relevant, they do not, in fact, deviate our focus from our priorities, which is to perform a historical analysis of the peculiarities of the Nordic working life research. It seems that the collaboration in the labor market and recognition of mutual legitimate interests have formed the foundation for studies of the Nordic working life, and as such, it is the consequences of these features that we analyze in this paper. We have, therefore, selected "collaboration" and "employee influence" as the key areas where distinctive contributions from Nordic working life research can be expected.

\section{Selection of key research contributions}

Nordic working life research is extensive. It covers a broad spectrum of issues and topics, and uses many different theoretical and methodological approaches. The result is therefore a multifaceted research that cannot adequately be described by a few characteristics. The challenge is therefore to exercise a filter to find those research approaches that aim to identify key contributions from Nordic working life research that do not stereotype the research into uniform models that are far removed from the reality in research practice.

Initially, we performed a broad search in research databases for peer-reviewed articles published within the last ten years to identify particular patterns of perspectives on Nordic working environment research. We limited the search strings to contain keywords related to the terms "collaboration" and "influence/participation/control" in combination with "work(ing) environment" and "Nordic/Scandinavian/Danish...." We thereby excluded articles that primarily seem to discuss topics such as motivation, learning, labor markets, regulation, and occupational medicine. These topics could also have been relevant to our analysis, but we excluded them as we were looking for particular distinguishing roots of Nordic working life research which we assessed would take collaboration and influence as the point of departure. 
Within each subject we found several articles published by Nordic researchers, but the search results were widely scattered across many approaches and topics, and it was difficult to discern any particular pattern. The search results were discussed at a workshop with eight senior working life researchers representing the Scandinavian countries. The workshop concluded that it would be difficult or impossible to follow the aforementioned search strategy to identify specific Nordic research perspectives. The experts gave several reasons: 1) even within the last ten years, many Nordic research publications have only been published in national languages and not been published in international peer-reviewed journals, 2) the Nordic approach to working environment research has been shaped by a longer tradition that reaches further back than ten years, and 3) due to their narrow character, peer-reviewed journal articles will only provide a relatively fragmented picture of Nordic research perspectives. So, the literature analysis should also include books and research reports published in national languages.

The workshop concluded that the primary value derived from the initial database search was the references obtained to older literature in the field. The experts at the workshop presented their views of the particularities of the Nordic research traditions and proposed two particular fields as paradigmatic of the Nordic approach: worker influence/control (especially including action research) and socio-technical systems. It was also proposed that a particular Nordic perspective concerned itself with employee well-being rather than employee sickness. The experts opined that for a comprehensive understanding of the Nordic research perspective, the literature analysis should not be limited to peer-reviewed articles but should also include books and research reports published in national languages.

When we pondered over the recommendations of the senior researchers, we had to conclude that an extensive review of the books, papers, and research reports published in national languages dating back to several decades was too large a task to be completed within the project. Ensuring a reasonable coverage would require visits to local universities and libraries in the Scandinavian countries. We therefore decided to follow another strategy. We chose to identify and analyze paradigmatic contributions in Nordic working life research that stand out as especially salient for subsequent research. For each of these contributions we identified one or two distinctive historical sources that have been widely used and referenced in subsequent Nordic working life research. Based on the conclusions of the workshops we decided to analyze three historical key research contributions that have focused on:

- the workers' collective (Lysgaard, 1961).

- socio-technical systems (Emery \& Thorsrud, 1976; Thorsrud, 1977; Thorsrud \& Emery, 1970).

- control over and in work (Gardell \& Svensson, 1981; Karasek, 1979; Karasek \& Theorell, 1990).

These classic contributions were published during the period from the late 1950s to the early 1980s. Our analysis of these historical sources concentrates on the particular setup, the empirical background, and the theoretical contribution of each of the above selected works especially on the findings regarding collaboration and worker influence. Two types of readings were performed: a concrete reading aiming to identify the theoretical and methodological setup used by the researchers and a hermeneutical reading 
aiming to identify research ideas, basic patterns of thinking, and overall conclusions. The initial interpretations were discussed in the research group and with the group of experts. The works were reread and reinterpreted in light of the discussions and comparisons of the works. Subsequently, the interpretations were discussed in the research group again. Finally, selected parts of the works were reread and reinterpreted during the writing and revision of this paper. We concluded the analysis with a discussion of the newer research that builds upon the classical contributions, and this discussion includes concepts such as the good work, developmental work, and meaning of work.

\section{Selected classics of Nordic working life research}

\section{The workers' collective}

The notion of "the workers' collective" (arbeiderkollektivet) has had a large impact in the Nordic countries at the workplace level; and has become a common term when talking about strongly united and collectively acting workers. The term was first coined by Sverre Lysgaard (1961) in his book of the same name. Lysgaard wanted to develop a sociological theory about and for the subjugated at the workplace ("de underordnedes sociologi").

Hernes et al. (1982) consider the 1950s, the period when Lysgaard's work was conducted, as an empirically grounded "golden age of sociology" in Norway. We have chosen to present Lysgaard's work first, although the work was published in 1961 after the first contributions of the socio-technical school had been published in England (Rice, 1958; Trist \& Bamforth, 1951). However, the major breakthrough in socio-technical thinking in the Nordic countries was first published a decade or so later (Emery \& Thorsrud, 1969) and independently of Lysgaard's work; and it is generally difficult to determine who inspired Lysgaard, as the references in his text are somewhat vague (e.g., “... as assumed in sociology ...”).

Lysgaard's work shares two features with the aforementioned socio-technical research. It is highly empirical using anthropologically related methods and is inspired by systems theory. Methodologically, Lysgaard's (1954) analysis is based on a study of the company: “M. Petersen \& Søn A/S Cellulose." The company was a paper factory with 735 employees. Four research assistants from the research institution interviewed 252 workers, foremen, and managers. Interviews lasted up to ten hours. The researchers observed work processes for eight weeks by participating as coworkers and they also observed meetings at all levels of the organization.

Lysgaard's "discovery" was that the workers acted as a collective in relation to the management, so he coined the phrase "the workers' collective." The discovery has parallels to Taylor's notion of "soldiering" similarities to observations made in the Hawthorne studies reflecting that workers may create their own standards for how they perceive a reasonable workday should be (i.e., working slower than they could). The difference between Lysgaard's and Taylor's notions is that Lysgaard explains this mechanism as a natural and legitimate defense for the "limited," "multifaceted," and "security needing" worker who is pitted against the one-sided, indefinite demands of the techno-economic system. Lysgaard's point was that workers assume the power to humanize work by acting and negotiating collectively. He identified a "we against them" division between the workers and the management. 
A strong workers' collective does not allow individual coworkers to negotiate directly with the techno-economic system represented by the management. Lysgaard, in his analysis, describes an instance where a manager reaches agreements with certain individual workers about the level of the piece rate payment, but the changes were stalled when they were about to be implemented because the workers' collective had changed their mind by then. Lysgaard calls this phenomenon "a collective control ideology" that works in the interest of the collective by excluding (and sometimes even punishing) workers who do not comply with the interests of the collective.

Lysgaard further argues that although the workers' collective serves to protect the interests of the employees, it is neither systematically designed nor necessarily consciously maintained, and it only emerges under certain conditions. It could also be described as a workplace culture (Schein, 1992), and had he conducted the analysis a decade or two later, Lysgaard might have used the culture metaphor instead of, or in addition to, the systems metaphor.

Lysgaard identifies three mutually interacting preconditions for the emergence of a strong employee collective: proximity, similarity, and problem conditions. Proximity conditions mean that unless the employees meet and interact with each other in connection with the production process, it is difficult for a collective to emerge. Similarity conditions mean that employees should be able to identify with each other, for example, based on similarity in educational background, work tasks, or working conditions. Proximity conditions might be less important, if such similarity is high. Problem conditions are about the issues the employees face because of the demands of the technoeconomic system. The greater the dilemmas perceived by the employees, the greater is the perceived need for protection. Proximity conditions and similarity conditions play important roles in the emergence of a strong employee collective, and they may even re-condition employees as to how they perceive of common problems.

Lysgaard shows convincingly that when a workers' collective gains strength as it did in the case study, it "infiltrates" the management system, for example, by influencing how common problems are defined and perceived (problem conditions), by affecting who will be hired and fired (similarity conditions), and by creating opportunities for workers to meet and discuss (proximity conditions). When combined with a strong internal discipline, the collective creates a self-perpetuating mechanism that preserves and endeavors to continuously strengthen its power.

It is clear from Lysgaard's description that a powerful workers' collective does have certain consequences for the individual workers in that while the workers are protected from the relentless techno-economic system, they are also forced to compromise on their personal interests and values. A strong collective may even endanger the company's profitability. The workers' collective may be at odds with formal worker representation, because it emerges as an informal, non-democratic system, potentially in conflict with ideas of workplace democracy. Nevertheless, Lysgaard's study does illustrate the details of how the subjugated get access to power to counter the relentless demands of the techno-economic system without hiding any negative consequences it may have.

The point we want to make regarding Lysgaard's theory is that his study shows that workers, acting collectively in the right preconditions, may get to achieve the power to counter the demands of the techno-economic system. Lysgaard may well be criticized for 
being too simplistic in his description of the systems components, especially in his claim that workers are exposed unmediated to the demands of the techno-economic system. In Lysgaard's description, the managers do not play any independent role in shaping acceptable working conditions, for example, by modifying the relentless demands to achieve the best possible results given the resources of the workforce. However, such reservations do not change the fact that Lysgaard succeeds in outlining a research perspective whereby workers act collectively trying to improve their working conditions to alleviate the subjective consequences of relentless workplace demands and to compel management to negotiate terms and conditions of work.

Today, because employee protection has improved significantly and workers participation has been institutionalized in the Nordic countries, classical workers' collectives may seem archaic to contemporary observers, although examples of strong classical workers' collectives can still be encountered in some workplaces. In contemporary Nordic research publications, the term "workers' collective" is rarely used, but it is widely accepted that employees participate and act collectively in the workplace.

\section{Socio-technical systems}

The Tavistock traditions of socio-technical systems "reached" the Nordic countries through collaboration in Norway between Einer Thorsrud, Eric Trist, and Fred Emery (both from Tavistock). Though Emery and Thorsrud have contributed several books, their main work was published in 1970 (Thorsrud \& Emery, 1970). The work summarizes the results of the collaborative experiments they conducted in the 1960s in industrial companies in collaboration with the Norwegian employers' organization and the Norwegian Trade Union Congress (TUC). The results were also published in English (Emery \& Thorsrud, 1976; Thorsrud, 1977).

Emery and Thorsrud focused on conducting field experiments aimed at improving the conditions for employee involvement in daily work. These field experiments were set up to explore how the detrimental effects of Tayloristic mass production work-forms could be prevented. In addition, these experiments were critical to the human relations movement that only seemed to focus on management-worker relations without considering the technical setup. The experiments were agreed upon and supported by the employers' associations in collaboration with the Norwegian TUC. They were part of a larger movement toward increased industrial democracy and increased employee involvement.

The empirical foundations for Emery and Thorsrud's work are four detailed case studies in the companies where the "job redesign" and "increased team autonomy" experiments were conducted for several months at a time, during a period of three to four years. The book describes in detail the interactions with the national actors and the activities and implementations in these companies. The authors do not account for the character, number, and length of interviews conducted, but they do provide an eightpage guideline of how to conduct socio-technical interventions (Thorsrud \& Emery, 1970, pp. 209-217).

One of the most important contributions of Emery and Thorsrud was their emphasis on workers' psychological needs that work should fulfill. The provisions of such rewards as wages, appropriate working hours, safety from damage, and protection against 
arbitrary dismissal are deemed important but insufficient. Emery and Thorsrud have summarized workers' psychological job demands as follows:

- content of work.

- extent of learning at work.

- ability to make decisions about their own work.

- having reputation, support, and respect.

- experiencing cohesion between the work and the outside world.

- prospects for the future.

According to Emery and Thorsrud, while these demands can be used as basic guidelines for designing and reorganizing work tasks, the demands have to be tailored to the specific work setup and incorporated in the technological design at the workplace. They cannot be implemented as generic organizational structures and one should always view the social and technical processes as one unified system and not as two independent systems.

Emery and Thorsrud present a number of principles for the reorganization of work which they believe should be introduced in most workplaces to meet the psychosocial demands of workers.

At the individual level, work design should include:

- optimal variation in work tasks (avoiding too little or too much variation).

- a meaningful pattern of tasks that present itself as a single primary task.

- an optimal cycle length that ensures a good working rhythm.

- opportunity to set targets for production and be informed about the results.

- expansion of the job to include "boundary tasks" or "service work".

- work should require a minimum of mental challenges, skill, and effort.

- contribute to the product or service-utility to the consumer.

At the group level, work tasks should be linked, rotated, and arranged in physical proximity, if:

- similarities between the work tasks allow for it.

- the tasks involve strong mental strain (stress).

- the task's contribution to the final product is not transparent.

If work tasks are bundled or job rotation is introduced, the collection of tasks should:

- appear as a single primary task that contributes to a useful product.

- allow for setting up norms for the result and receiving information about the results.

- involve control of the border tasks (voluntary tasks or services).

In their book, Emery and Thorsrud explicitly state that employees need control of their own work situation, and this influence in work has an impact on individual employees' well-being and on their productive contributions at the workplace. Where Lysgaard focused on how the workers as a collective could seize power to influence their work situation, Emery and Thorsrud described how work could be structured to secure influence 
in daily work, which can also be construed as counter-power versus co-power in relation to management. However, although Emery and Thorsrud include suggestions to increase employee influence at both the individual and group levels to increase cooperation, their version of socio-technical theory has been criticized for having too much focus on individual issues (Falkum et al., 2009).

The main points we want to make from the contribution of Emery and Thorsrud is that they provide recommendations for increasing workers' influence in work because they consider workers as subjects with a need for meaningful tasks, developing jobs, and a healthy working rhythm. These recommendations may restrict the freedoms of the employers in designing jobs while conceding more power to employees, but the authors also argue that employers do stand to benefit from a more flexible and motivated workforce. They go so far as to state that in their framework "the primary function of management is the regulation of framing conditions and not internal control" (Thorsrud \& Emery, 1970, p. 172). They also indicate and demonstrate in the field studies that an alternative job design strategy is realistic and worth pursuing to fulfill employees' psychological needs and productivity requirements at the same time. They further demonstrate that cooperation between the social parties at both central and local level is beneficial for both the parties.

Today, the contributions of Emery and Thorsrud are still relevant in terms of cooperation, influence, and the meaning of work. Their results have been incorporated in contemporary job design models (Holman, 2013; Parker et al., 2001). Although automation is able to remove some tasks that can be performed without much variation, automation may also create jobs with low variation. The socio-technical approach is therefore still highly relevant as an analytical perspective focusing on human needs for influence at work and for variation. Some modern management concepts such as Lean incorporate ideas from socio-technical thinking, but the outcome of using such management concepts typically depends on the character of the governance system they are implemented in. Influence, variation, and cooperation are not guaranteed in such systems (Westgaard \& Winkel, 2011).

\section{Control over and in work}

In addition to the two classics described above, we have also identified two major interrelated developments in the Nordic working life research. First is the research of Gardell and Svensson (1981) that points toward industrial democracy through an integration of ideas from Lysgaard's workers' collective with ideas from the socio-technical theory of Thorsrud and Emery. Second is the research of Karasek and Theorell (1990), corroborating the influential demand-control model introduced by Karasek (1979).

In the introduction to Gardell and Svensson's book about co-determination and self-government, the authors point out that workplace democracy was a key strategy for employee organizations in Sweden in the 1960s and 1970s. However, although there had been very convincing demonstration projects in both Norway and Sweden, based on Thorsrud and Emery's work, these projects remained lone insignificant attempts, and no learning was created in other companies. Most of these projects had been initiated by employers and their main focus had been on the influence on their immediate tasks (influence in work). 
Gardell and Svensson promoted a different strategy where democratization and control of work should be initiated by the local employee organizations in collaboration with local management. They built the strategy based on the experience from a case study involving the industrial company Almex, a producer of ticketing machines, with 264 employees. The researchers observed the company's production processes and conducted interviews almost everyday for a duration of one year. In the first phase of the study, they used semistructured interviews to interview all employees in all the autonomous work-groups in the company-about 60 blue-collar workers, and additionally 30 white-collar workers. In the second phase, they interviewed about 100 blue-collar workers using structured interviews with fixed response categories. All interviews were held anonymously.

The developments at Almex started because a group of workers were dissatisfied with the lack of local union activity. In the early 1970s, a group of eight workers started a study group on how to improve working conditions and how to increase their influence over and in work through autonomous work-groups. In 1972, the local union club elected a new board, and a group of eight employees conducted a literature study of alternative organizational principles from 1972 to 1975. The group approached the managing director, who appreciated the initiative, and in 1976 the collaboration committee (Företagsnämnden) appointed a committee with the purpose of implementing autonomous work-groups in a step-wise process. These initiatives led to fundamental changes at Almex and $75 \%$ of the departments had implemented autonomous workgroups when the research was conducted in 1978/79.

Gardell and Svensson conceptualize the developments at Almex as an extension to the framework developed by Lysgaard, while including the benefits of socio-technical design as described by Thorsrud and Emery. The workers' collective acquires part of the responsibilities of the techno-economic systems by taking over the planning and management of local group activities. As the influence of the workers' collective increases, the employees gain more control over work. The control over work also increases because the work-group takes over responsibility for many work processes.

Gardell and Svensson thought that the new bottom-up approach based on employee learning would be a better strategy for a widespread dissemination of industrial democracy. They summarize how the bottom-up strategy of Almex differs from previous development strategies for involvement and industrial democracy:

- a multiple-level strategy where participation, group autonomy, and individual selfdetermination are united;

- a development from below based on workers' initiative and engagement supported by top management;

- a collective and inclusive approach where the local club of the union tried to avoid competition within and between stakeholders;

- step-wise initiatives developed and introduced gradually and the organization is not seen as fully developed after the initial change;

- local cooperation between blue- and white-collar workers (SvenskMetall and SIF);

- a strategy of spreading knowledge directly to other local clubs in the union (metal workers union) and to ensure diffusion of the ideas through research.

Considering the societal developments that have taken place since the release of Gardell and Svensson's book, one must conclude that the Almex model did not disseminate 
widely through the Swedish Metal network. On the contrary, contemporary researchers conclude that most autonomous work-groups are part of management systems where they are under close control system-for example, through employers' embracement of Japanese production methods such as lean and total quality management (Knudsen et al., 2011; Westgaard \& Winkel, 2011). There were, however, high-profile examples such as the Volvo Uddevalla-factory (Sandberg, 1995). Sweden conducted several large government programs to boost local business development in the 1990s (Gustavsen, 1998; Oscarsson, 2004) and a similar program was conducted in Norway (Finsrud, 2009; Gustavsen, 2011).

In contrast, Karasek's demand-control model has been immensely influential in research inspiring thousands of research projects and articles worldwide (Belkic et al., 2004; Egan et al., 2007; Van der Doef \& Maes, 1999). The demand-control model was first introduced in an article by Robert Karasek in 1979 after a couple of years of research on a Fulbright scholarship in Sweden. It was the subsequent collaboration with Swedish researchers and the use of Swedish population data that gave the model its initial empirical momentum (Karasek \& Theorell, 1990).

A great achievement of Karasek and Theorell is that the demand-control model combines theories of stress with theories of leadership, organization, and productivity. Thereby, stress research became less oriented toward individual coping, and the model contributed to the emergence of the concepts of "healthy work" and "psychosocial work environment." The model emphasizes three key organizational and managerial factors: influence, collaboration, and learning.

Contrary to the previously mentioned books, the work of Karasek and Theorell is not based on detailed qualitative empirical studies. It is instead based on several large population surveys, particularly data from national quality of employment surveys in the United States $(1969,1972$, and 1977) and Sweden (1968), and health data from both countries such as blood pressure and risk of coronary heart disease.

With the publishing of their book, Karasek and Theorell intended to support the movement toward industrial democracy. Although the model is specifically related to influence in work, the authors stress that changes introduced from above are likely to fail if they do not have the support of employees, and more importantly, such changes will not reflect a democratic value structure in the workplace.

However, in the aftermath, this democratic outset has not been the most prevalent use of the model. On the contrary, the model has been the basis for numerous scientific articles based on epidemiological quantitative research trying to prove or disprove the model. Many articles do simply overlook or ignore the democratic tenet and that workplace learning is at the heart of the theory (see Figure 1 that illustrates the learning mechanisms induced by higher decision latitude). By increasing their influence in work, employees have better chances for adapting working procedures to their needs and thereby for learning and developing on the job. On the other hand, the quantitative research has given the model a momentum that may have disseminated the central message about the benefits of influence in work (decision latitude) much wider (worldwide) than the other key contributions described above, however, without the central learning and development point.

The main point we want to draw from the contributions of Gardell and Svensson (1981) and Karasek and Theorell (1990) is that they are exponents of two quite different approaches to influence in work: control over and control in work. Both contributions 
Figure I: The Karasek demand-control model including dynamic associations.

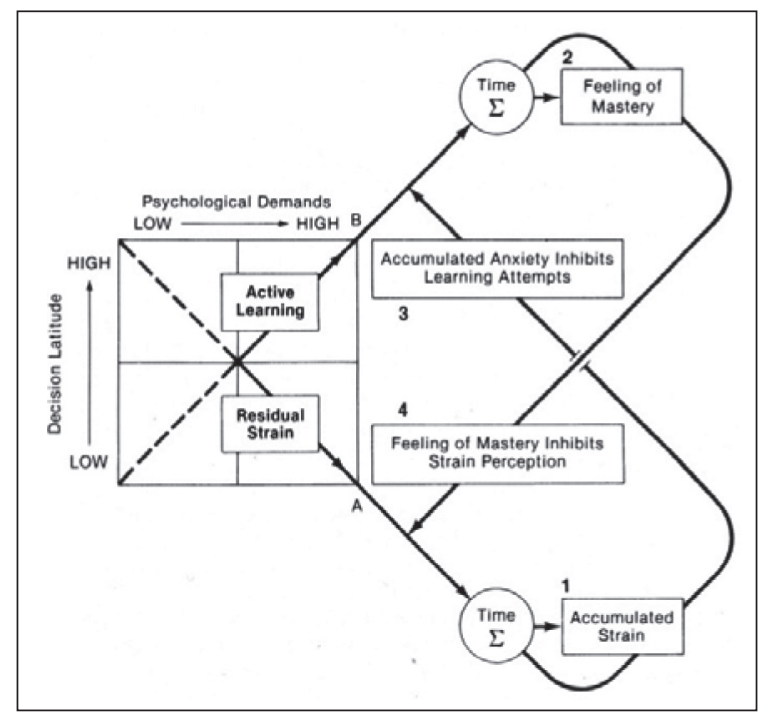

view the workers as active subjects capable of forming their own work to increase their learning and improve job quality. The focus on the transformational powers of the workers' collective is central in the work of Gardell and Svensson, whereas it is a matter for central stakeholders in the work of Karasek and Theorell-which may explain why it has been possible to decontextualize the demand-control model from the Nordic collaborative context (and having it return wrapped in Anglo-Saxon management concepts).

The ideas put forth by Gardell and Svensson about the self-managed work-groups have become relatively mainstream in the Nordic countries; however, these ideas have not been tightly associated with an increase in workplace democracy. The same applies for other non-Nordic management concepts involving self-managed work-groups. The Karasek framework has, on the other hand, become immensely influential. It has become central to the regulatory activities performed by the working environment authorities.

\section{The Nordic contributions}

The question is what kind of cross-cutting contribution can be drawn from these three aforementioned classic research works? A short summary can highlight one such contribution. Lysgaard proved that employees more or less consciously create a collective that shares interpretations, attitudes, and norms for their work, and that they use this collective to influence their own working conditions. The socio-technique as flagged by Thorsrud and Emery showed that the employees are not only interested in their salary but also in the content of their work, and that organizational forms where employees can use their abilities are beneficial for employee well-being and productivity (especially teamwork). Inspired by both these works Gardell, Karasek, and Theorell showed 
how employees could actively shape both the content and form of their own work and thereby increase both well-being and productivity.

Looking across these three classic works, there emerges one cross-cutting contribution. It is the understanding of the employees as autonomous subjects, both individually and collectively, who actively involve themselves in their work situation, not only to achieve personal benefits but also to create meaning out of their core tasks with a view to contribute toward achieving the goals of the organization.

The distinctiveness of this contribution can be assessed by comparing it with some of the major international working life research traditions. We are aware of the risks involved in making such a comparison. In order to do the comparison in a meaningful way, it is necessary to make a rather gross description of the common characteristics excluding the finer distinctions of the traditions-even those distinctions that point toward possibilities for a convergence toward the Nordic approach. Nevertheless, such a comparison can be used to create a contrast that can highlight the Nordic working life research paradigm. We have chosen to compare the Nordic paradigm with three major research traditions: labor process research, occupational medicine, and human resource management.

We have selected two dimensions to consider when comparing these research traditions. The first dimension of comparison is whether the research is dominated by an individual or a collective perspective, and the second dimension is whether employees are mainly considered as objects for researching working conditions or they are considered as subjects with their own autonomous aspirations (Figure 2).

The first major research tradition is labor process research with its point of departure in Marxism and Braverman (1974). It has an understanding of the employees as a

Figure 2: The Nordic research perspective compared with other major research traditions.

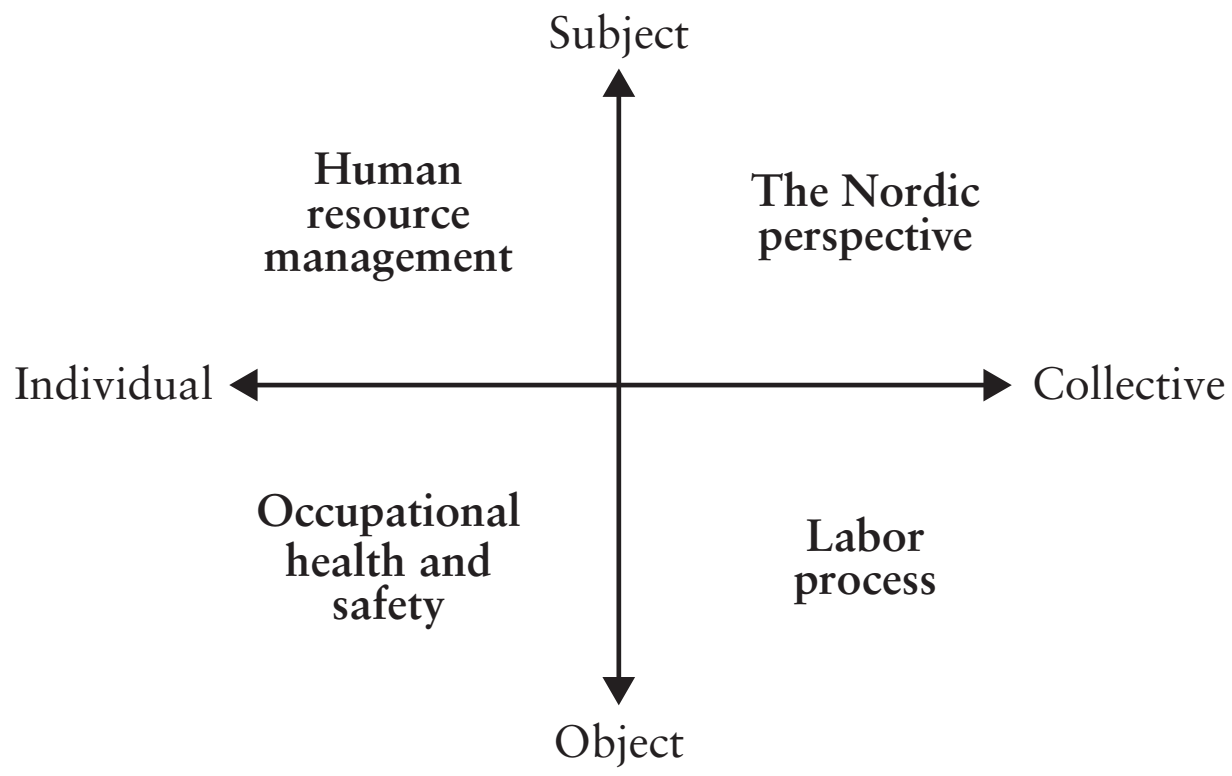


collective and focuses on the shared condition that the employees share. The tradition predominantly views employees as objects who are subject to economic exploitation due to the private capital ownership of the workplaces. Therefore, employees are typically considered as a collective resisting exploitation, but not as active subjects who have a genuine interest in the meaning of work and contribution to core tasks (Thompson, 1989). As an example, meaning of work is hardly mentioned in a 460-page critical introduction to work organizations (Thompson \& McHugh, 2002). Even questions of consciousness and identity tend to be considered through resistance lenses (Burawoy, 1979). We are aware that this rather coarse description of labor process research does not give credit to new developments that have taken place during the last few years which have, among others, developed concepts such as high involvement work systems, which is perhaps closer to the Nordic tradition (Appelbaum et al., 2000; Harley et al., 2010). However, some theorists argue that high involvement work systems are not a part of the labor process tradition and it is also being heavily debated whether such a concept is of any benefit for the workers (Danford et al., 2008). We believe that the assertions we make about labor process research hold true for a core of research from the early 1970s up to the most recent years (Thompson \& Smith, 2010).

The second major research tradition is occupational health and safety research or occupational medicine. In this case, while the interest is on the fraction of the individuals who seem to suffer from occupational diseases, the question is one of getting sick employees back to work or about controlling risky behavior at the workplace (LaDou, 2006; The Joint ILO/WHO Committee on Occupational Health, 1950). Health and safety research considers employees as objects who are exposed to risks independent of their individual aspirations. This coarse characterization of health and safety research can be criticized for overlooking many recent developments, especially the research on psychosocial factors that has included newer perspectives (Bakker \& Demerouti, 2007; Semmer, 2011; Semmer et al., 2007; Siegrist et al., 2004), but the dominating trend is still to label psychosocial factors as risk factors, thereby maintaining the definition of an objective risk independent of employee aspirations (Eurofound, 2012; Leka et al., 2011).

The third major research tradition is human resource management which traces its roots back to both scientific management (Taylor, 1911) and human relations with the famous Hawthorne studies (Mayo, 1945). Although both of these studies took an interest in groups at work, the focus was on the individual motivation for work and that trend has since dominated the tradition (Boxall \& Purcell, 2008; Hersey \& Blanchard, 1977; Legge, 1995). The employees are understood as individuals who possess individual competences and personal aspirations in their careers. It is therefore a subjective perspective where human resource management is interested in learning how individuals can be influenced to develop their competences and be as productive as possible. Even though there may be exemptions (Delbridge et al., 2011), human resource management does not have an understanding of employees as acting through a collective. The interest is on the individual employee acting on his or her subjective interests and aspirations.

Lysgaard's work has many affinities with the labor process theory and in many ways it is mostly about resistance strategies; however, as Gardell has shown, the resistance strategies create a power base that along with cunning professional strategies can be used to interact with progressive managers to improve working conditions, for example, by creating autonomous work-groups. Thorsrud's work was heavily influenced by the British socio-technical tradition, but it acquired a particular corporatist flavor when it 
was adapted in Norway (Heirat, 2003). The demand-control framework was directly imported from the United States by Karasek, but it also acquired a particular Nordic flavor when learning, development, and workplace democracy were added to the description of the theoretical framework. Other European countries also have elements similar to the Nordic perspective, such as the German work development programs and the Dutch collaborative system. Despite these international influences and affinities, we believe it is reasonable to talk about a particular Nordic approach to working life research.

The Nordic research perspective deviates from all these three major traditions with the understanding that employees are autonomous beings who not only have objective interests and individual aspirations, exposed to objective risk factors, but are also occupied with the meaning of work. Meaning grows out of the social relations with their colleagues, and they individually as well as collectively try to influence and increase meaning (Isaksen, 2000; Kamp, 2011). One important position is that the legitimacy of employee interest and influence have a value by themselves. It is not just a question of using employee participation as a tool to achieve enterprise interest as expressed by top management but as a value in itself in an egalitarian and democratic society, which also implies that top management does not have a monopoly over the interpretation of the best interests of the enterprise (Hasle et al., 2010; Kettunen, 2012).

The Nordic action research tradition has grown out of the interest in engaging with reflexive subjects in the field to create meaningful research results that are beneficial for all actors involved using research methods that respect and develop democracy. We see the central tenet of action research as a direct extension of the key contributions presented above: involve the knowledge of stakeholders and create possibilities for cooperation. Thorsrud's collaborative experiments were the beginning of the tradition in Norway, and through the 1970s and 1980s many researchers became engaged in practical collaboration with companies about the development of work and organization. Some of the best known Nordic exponents of action research are Gustavsen $(1992,1998,2007)$ and Levin (Greenwood \& Levin, 2007). Both researchers have been deeply involved in collaborative research involving stakeholders from all levels of society (workplace, unions and employers' associations, local and central political levels). Gustavsen, for instance, has been responsible for the development and implementation of a wide range of search conferences in Norway and Sweden for their governments and social partners. However, there have also been strong proponents for action research in Sweden and Denmark, such as Nielsen and Svensson (2006).

\section{Perspectives}

The understanding that employees are autonomous beings possessing both individual and collective aspirations has played a dominant role both at the societal and research levels in the Nordic countries. The unions launched new work-life programs in the late 1980s and early 1990s (the good work in Sweden and the developmental work in Denmark (Hvid \& Hasle, 2003), which to a large extent were built upon the aforementioned research. These programs were later followed up in the 1990s by the governments in Sweden, Norway, and Denmark who launched large workplace development programs greatly inspired by research (and the union programs) which had researchers 
involved both in program development and in the subsequent evaluations. Some examples are the LOM-program in Sweden, BU-2000 in Norway, and the program for the developmental work in Denmark (Gustavsen, 2011).

The classic research works with this particular understanding of the employees form an important basis for Nordic working life research. Using Denmark as an example, some of the important issues at the moment are organizational social capital (Hasle et al., 2010), meaning of work (Kamp, 2011), and lean as a possibility to integrate productivity and the working environment (Edwards et al., 2010). This research considers the employees as collectively acting subjects who are motivated to influence the content and conditions of their work, while seeking and constructing meaning from their work activities, actively involving themselves in implementation of lean. Heirat (2003) has made a similar point regarding the TQM movement in Norway, emphasizing that TQM was adapted to the Norwegian cooperative model and that it in some cases strengthened the Norwegian model because it linked direct participation with the joint decision-making system.

At the same time, Nordic working life research is getting more intertwined with international research. Nordic researchers are writing more in English, thereby opening the Nordic model up to international researchers, and they are also integrating internationally developed theories and empirical findings into their own research. One example is the Karasek demand-control model which was developed in Sweden to find a way to involve more active learning in jobs, but this angle was forgotten in international research which grasped it as a model for stress research while mainly using the model to identify risk factors for stress-related diseases. The model then returned to the Nordic countries and made a strong impact on working environment regulation of psychosocial factors at work. In parallel with this development, the demand-control model has also had an impact on the development of the ideas for the good work and the developmental work. In a similar vein, the new research issues in Denmark all have been strongly influenced by international research.

However, it is still important for us to emphasize that Nordic working life research has also been strongly influenced by the fact the Nordic welfare society models have been challenged in recent years. Stronger global competition, demographic changes, individualization, and public sector budget constraints have posed serious threats to the welfare state. The important challenges for the labor market are increasing trend of outsourcing of industrial jobs, immigration of foreign labor especially from Eastern Europe, falling union density, and strong international competition on both costs and innovation. Nordic working life research is therefore also occupied with the study of both the consequences of these developments and exploring the possibilities to meet these challenges while maintaining key elements of the welfare system. Research in lean can be used as an example. There is criticism of the consequences of lean, particularly in the public sector (Trägårdh \& Linberg, 2004), and there are attempts to develop a Nordic approach to lean, using the tradition for employee involvement to develop lean models with a stronger bottom-up element (Hasle, 2011). A recent large review of the consequences of rationalization such as lean has proved that, in most cases, rationalization had negative consequences for employee health and well-being but involvement of the employees in accordance with the Nordic tradition reduced or even removed the negative effects (Westgaard \& Winkel, 2011).

The important question is whether the distinct Nordic understanding of employee interest as legitimate and as equal to management interest can survive in the future. 
Lower union density and management's interpretation of the global competition may challenge the legitimacy of employee interests. Management may consider employee involvement as a time-consuming burden in times when quick decisions are required, and if the membership is low, the urge to involve employees may be even lower. At the same time, there are also cases showing how the employees headed by shop stewards have had a strong hand in securing competitiveness in multinational corporations (Kristensen $\&$ Lilja, 2011).

At a time when the Nordic welfare society and the collaborative labor market have been challenged, there are still certain unique possibilities in the Nordic countries, when compared with many other industrialized countries. The task for contemporary working life research is therefore twofold: on the one hand there is a need to uncover the consequences of the challenged Nordic model and on the other hand there is a need to find ways to overcome the challenges of working life in such a way that employees can maintain and develop their possibilities as autonomous subjects.

\section{Acknowledgement}

The research has been supported by the Nordic Council of Ministers. Great thanks go to the group of researchers who provided valuable assistance during the selection and interpretation of the Nordic working life research literature: Jan Karlsson, Per Øystein Saksvik, Helge Hvid, Klaus T. Nielsen, Asbjørn Grimsmo, Kaj Frick, Jørgen Winkel, Gunnar Aronsson, Marit Christensen, and Annette Kamp.

\section{References}

Appelbaum, E., Bailey, E., Berg, P., \& Kalleberg, A. L. (2000). Manufacturing advantage. Why high-performance work systems pay off. Ithaca \& London: Cornell University Press.

Bakker, A. B. \& Demerouti, E. (2007). The Job Demands-Resources model: state of the art. Journal of Managerial Psychology 22(3): 309-328.

Belkic, K. L., Landsbergis, P. A., Schnall, P. L., \& Baker, D. (2004). Is job strain a major source of cardiovascular disease risk? Scandinavian Journal of Work Environment \& Health 30(2): 85-128.

Bjørnskov, C., Svendsen, G. T., \& Svendsen, G. L. H. (2011). På sporet af den skandinaviske tillid [On the track of Scandinavian trust]. In P. Hegedahl \& G. L. H. Svendsen (Eds.), Tillid-samfundets fundament [Trust-the pillar of society] (pp. 127-140). Odense: Syddansk Universitetsforlag.

Boxall, P. \& Purcell, J. (2008). Strategy and human resource management. (2nd ed.) Basingstoke \& New York: Palgrave Macmillan.

Braverman, H. (1974). Labor and monopoly capital: the degration of work in the twentieth century. New York: Monthly Review Press.

Burawoy, M. (1979). Manufacturing consent. Chicago: University of Chicago Press.

Danford, A., Richardson, M., Stewart, P., Tailby, S., \& Upchurch, M. (2008). Partnership, high performance work systems and quality of working life. New Technology Work and Employment 23(3): 151-166.

Delbridge, R., Hauptmeier, M., \& Sengupta, S. (2011). Beyond the enterprise: broadening the horizons of international HRM. Human Relations 64(4): 483-505. 
Due, J., Jensen, C. S., Madsen, J. S., \& Petersen, J. K. (1994). The survival of the Danish model. Copenhagen: DJØF Forlagene.

Due, J. \& Madsen, J. S. (2008). The Danish model of industrial relations: erosion or renewal? Journal of Industrial Relations 50(3): 513-529.

Edwards, K., Bojesen, A., \& Nielsen, A. P. (eds) (2010). Lean og arbejdsmiljø—et dynamisk spondingsfelt [Lean and the working environment-a dynamic field in tension]. København: L\&R Business.

Egan, M., Bambra, C., Thomas, S., Petticrew, M., Whitehead, M., \& Thomson, H. (2007). The psychosocial and health effects of workplace reorganisation. 1. A systematic review of organisational-level interventions that aim to increase employee control. Journal of Epidemiology and Community Health 61(11): 945-954.

Emery, F. E. \& Thorsrud, E. (1969). Form and content in industrial democracy. London: Tavistock.

Emery, F. E. \& Thorsrud, E. (1976). Democracy at work-The report of the Norwegian industrial democracy programme. Leiden: Martinus Nijhoff Social Sciences Division.

Erikson, R., Hansen, E.J., Ringen, S., \& Uusitalo, H. (1987). The Scandinavian model. Welfare states and welfare research. New York: M.E. Shapes Publishers.

Esping-Andersen, G. (1990). The three worlds of welfare capitalism. Cambridge: Polity Press.

Eurofound (2012). Fifth European working conditions survey-overview report. Luxembourg: Publications Office of the European Union.

Fahlbeck, R. \& Mulder, J. (2009). Labour and employment law in Sweden. (3rd ed.) Lund: Lund University Faculty of Law Press.

Falkum, E., Hagen, I. M., \& Trygstad, S. C. (2009). Bedriftsdemokrati, medvirkning og medbestemmelse. Notat 1: Bedriftsdemokratiets historie i Norge [Workplace democracy, participation and influence. Notat 1: the history of workplace democracy in Norway]. Oslo: FAFO.

Finsrud, H. D. (2009). Den norske modellen og regionalisering av forskningen: Et nytt utviklingstrinn eller styrt avvikling. [The Nordic model and regionalization of research: a new development or controled dismantling]. Sosiologi i dag 39(1): 63-94.

Frick, K., Eriksson, O., \& Westerholm, P. (2004). Arbetsmiljöpolitik och arbetsmiljöaktörer [Health and safety policy and health and safety actors]. In R. Å.Gustafsson \& I. Lundberg (Eds.), Arbetsliv och hälsa [Working life and health] (pp. 381-409). Stockholm: Arbetslivsinstitutet \& Liber idéförlag.

Gallie, D. (2003). The quality of working life: is Scandinavia different? European Sociological Review 19(1): 61-79.

Gallie, D. (2009). Institutional regimes and employee influence at work: a European comparison. Cambridge Journal of Regions Economy and Society 2(3): 379-393.

Gardell, B. \& Svensson, L. (1981). Medbestämmande och självstyre-en lokal facklig strategi för demokratisering av arbetsplatsen [Influence or autonomy - a local professional strategy for democratizing the workplace]. Stockholm: Prisma.

Greenwood, D. J. \& Levin, M. (2007). Introduction to action research: social research for social change. Thousand Oaks: Sage.

Gudmundsson, G. (1993). Den nordiske model-en afklaring af begreber [The Nordic model一a clarification of concepts] (Rep. No. 646). Roskilde: Nordisk Ministerråd.

Gustavsen, B. (1992). Dialogue and development: theory of communication, action research and the restructuring of working life. Assen: Van Gorcum.

Gustavsen, B. (1998). From experiments to network building: trends in the use of research for reconstructing working life. Human Relations 51(3): 431-448.

Gustavsen, B. (2007). Work organization and 'the Scandinavian model'. Economic and Industrial Democracy 28(4): 650-671. 
Gustavsen, B. (2011). The Nordic model of work organization. Journal of the Knowledge Economy 2(4): 463-480.

Harley, B., Sargent, L., \& Allen, B. (2010). Employee responses to 'high performance work system' practices: an empirical test of the disciplined worker thesis. Work Employment and Society 24(4): 740-760.

Hasle, P. (2011). Lean production-an evaluation of the possibilities for an employee supportive lean practice. Human Factors and Ergonomics in Manufacturing \& Service Industries. In Print (Early view online): 1-14.

Hasle, P. \& Møller, N. (2007). From conflict to shared development: social capital in a tayloristic environment. Economic and Industrial Democracy 28(3): 401-429.

Hasle, P., Thoft, E., \& Olesen, K. G. (2010). Ledelse med social kapital [Leadership with social capital]. København: L\&R Business.

Heirat, J. (2003). International management strategies and models of industrial relation-a Norwegian experience. In D. Fleming \& C. Thörnqvist (Eds), Nordic management-labour relations and internationalization (pp. 103-130). København: Nordisk Ministerråd.

Hernes, G., Colbjørnsen, T., \& Knudsen, K. (1982). Klassestruktur og klasseskiller [Class structure and class divisions]. Oslo: Universitetsforlaget.

Hersey, P. \& Blanchard, K. H. (1977). Management of organization behavior: utilizing human resources. (3rd ed.) Englewood Cliffs: Prentice Hall.

Holman, D. (2013). Job types and job quality in Europe. Human Relations 66(4): 475-502.

Hvid, H. \& Hasle, P. (eds) (2003). Human development and working life. Aldershot: Ashgate.

Isaksen, J. (2000). Constructing meaning despite the drudgery of repetitive work. Journal of Humanistic Psychology 40(3): 84-107.

Jacobsen, K. (2011). Velfordens pris: Arbejderbeskyttelse og arbejdsmiljø gennem 150 ar [The price of welfare: Workers' protection and working environment the last 150 years]. København: Gad.

Johansson, J. (1998). Perspektiv på svensk arbetslivsforskning under 1900-talet [Perspectives on Swedish working life research in the 20th century]. In N. F. Christiansen, A. E. Hansen, \& N. Møller (Eds.), Arbejdet under forandring - forandring af arbejdet [Work in change-change of work] (pp. 286-302). København: Nordisk Ministerråd.

Kamp, A. (2011). Mening i arbejdet—for lidt, for meget, til forhandling? [Meaning at worktoo little, too much, negotiable?] Tidsskrift for Arbejdsliv 13(2): 8-27.

Kangas, O. \& Palme, J. (2009). Making social policy work for economic development: the Nordic experience. International Journal of Social Welfare 18: S62-S72.

Karasek, R., Gardell, B., \& Lindell, J. (1987). Work and non-work correlates of illness and behaviour in male and female Swedish white collar workers. Journal of Organizational Behavior 8(3): 187-207.

Karasek, R. A. (1979). Job demands, job decision latitude, and mental strain: implications for job redesign. Administrative Science Quarterly 24(2): 285-308.

Karasek, R. A. \& Theorell, T. (1990). Healthy work, stress, productivity, and the reconstruction of working life. New York: Basic Books.

Kasvio, A., Gonäs, L., \& Skorstad, E. J. (2012). In search of the Nordic working life model; introduction to the thematic issue. Nordic Journal of Working Life Studies 2(4): 1-19.

Kettunen, P. (2012). Reinterpreting the historicity of the Nordic model. Nordic Journal of Working Life Studies 2(4): 21-43.

Knudsen, H., Busck, O., \& Lind, J. (2011). Work environment quality: the role of workplace participation and democracy. Work, Employment \& Society 25(3): 379-396.

Kristensen, P. H. \& Lilja, K. (2011). Nordic capitalisms and globalization-new forms of economic organizations and welfare institutions. Oxford: Oxford University Press.

LaDou, J. (2006). Current environmental and occupational medicine. (4th ed.) New York: McGraw-Hill Medical.

Legge, K. (1995). Human resource management—rhetorics and realities. London: Basingstoke. 
Leka, S., Jain, A., Widerszal-Bazyl, M., Zolnierczyk-Zreda, D., \& Zwetsloot, G. (2011). Developing a standard for psychosocial risk management: PAS 1010. Safety Science 49(7): 1047-1057.

Lysgaard, S. (1961). Arbeiderkollektivet: en studie i de underordnedes sosiologi [The workers collective: a study of the subjugated' sociological]. Oslo: Universitetsforlaget.

Madsen, P. K. (2004). The Danish model of 'flexicurity': experiences and lessons. Transfer: European Review of Labour and Research 10(2): 187-207.

Mayo, E. (1945). The social problem of industrial civilization. Boston: Harvard Business School Press.

Nielsen, K. A. \& Svensson, L. (ed) (2006). Action research and interactive research. Mastricht: Shaker Publishers.

Oscarsson, B. (2004). Arbetslivsforskning i Sverige-Kort historik, nuläge och framtida inriktning [Working life research in Sweden-a short history, current status and future perspectives]. Stockholm: Fas \& Vinnova.

Parker, S. K., Wall, T. D., \& Cordery, J. L. (2001). Future work design research and practice: towards an elaborated model of work design. Journal of Occupational and Organizational Psychology 74(4): 413-440.

Philips, K. \& Eamets, R. (2007). Impact of globalisation on industrial relations in the EU and other major economies. Dublin: European Foundation for the Improvement of Living and Working Conditions.

Rice, A. K. (1958). Productivity and social organization: the Ahmedabad experiment, technical innovation, work organization and management. London: Tavistock.

Sandberg, Å. (1995). Enriching production: perspectives on Volvo's Uddevalla plant as an alternative to lean production. Aldershot: Avebury.

Schein, E. H. (1992). Organizational culture and leadership. (2nd ed.) San Francisco: Jossey-Bass.

Schiller, B., Venneslan, K., Ågotnes, H., Bruun, N., Nielsen, R., \& Töllborg, D. (1993). The future of the Nordic model of labour relations-three reports on internationalization and industrial relations. Nordisk Ministerråd.

Semmer, N. K. (2011). Job stress interventions and organization of work. In J. C. Quick \& L. E. Tetrick (Eds.), Handbook of Occupational Health Psychology (2nd ed., pp. 299-318). Washington D.C.: American Psychological Association.

Semmer, N. K., Jacobshagen, N., Meier, L. L., \& Elfering, A. (2007). Occupational stress research: the 'stress-as-offence-to-self' perspective. In S. Mcintyre \& J. Houdmont (Eds.), Occupational health psychology: European perspective on research, education and practice. Castelo da Mala: Ismai.

Siegrist, J., Starke, D., Chandola, T., Godin, I., Marmot, M. G., Niedhammer, I. \& Peter, R. (2004). The measurement of effort-reward imbalance at work: European comparisons. Social Science \& Medicine 58(8): 1483-1499.

Taylor, F. W. (1911). Scientific management. New York: Harper \& Brothers.

The Joint ILO/WHO Committee on Occupational Health (1950). Occupational health services and practice. Geneva: World Health Organization.

Thompson, P. (1989). The nature work-an introduction to debates on the labour process. (2nd ed.) London: Macmillan.

Thompson, P. \& McHugh, D. (2002). Work organisation. (3rd ed.) Hampshire: Palgrave.

Thompson, P. \& Smith, C. (eds) (2010). Working life: renewing labour process analysis. Basingstoke: Palgrave Macmillan.

Thorsrud, E. (1977). Democracy at work-Norwegian experiences with non-bureaucratic forms of organization. Journal of Applied Behavioral Science 13(3): 410-421.

Thorsrud, E. \& Emery, F. E. (1964). Industrielt demokrati: representation på styreplan $i$ bedriftene [Industrial democracy: representation at management level in companies]. Oslo: Universitetsforlaget. 
Thorsrud, E. \& Emery, F. E. (1970). Mot en ny bedriftsorganisasjon: Eksperimenter i industrielt demokrati [Towards a new work organization: experiments in industrial democracy]. Oslo: Johan Grundt Tanum Forlag.

Trägårdh, B. \& Linberg, K. (2004). Curing a meagre health care system by lean methodstranslating 'chains of care' in the Swedish health care sector. International Journal of Health Planning and Management 19(4): 383-398.

Trist, E. L. \& Bamforth, K. W. (1951). Some social and psychological consequences of the Longwall method of coal-getting. Human Relations 4: 3-38.

Van der Doef, M. \& Maes, S. (1999). The Job Demand-Control(-Support) model and psychological well-being: a review of 20 years of empirical research. Work and Stress 13(2): 87-114.

Westgaard, R. H. \& Winkel, J. (2011). Occupational musculoskeletal and mental health: significance of rationalization and opportunities to create sustainable production systems-a systematic review. Applied Ergonomics 42(2): 261-296. 